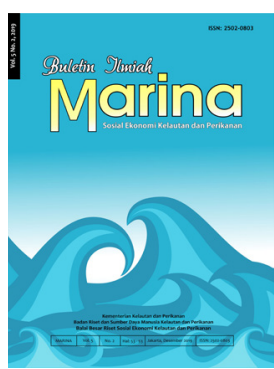

BULETIN ILMIAH MARINA

SOSIAL EKONOMI KELAUTAN DAN PERIKANAN

http://ejournal-balitbang.kkp.go.id/index.php/mra

p-ISSN: 2502-0803

e-ISSN: 2541-2930

Nomor Akreditasi: 30/E/KPT/2019

\title{
STRATEGI PENGEMBANGAN INDUSTRI PATIN DI PROVINSI JAMBI
}

\section{Strategies for Pangasius Industry Development in Jambi Province}

\author{
*Putinur, Randi B.S Salampessy dan Achmad Poernomo \\ Sekolah Tinggi Perikanan \\ JI. Raya Ps. Jati Padang, Kec. Ps. Minggu,Daerah Khusus Ibukota Jakarta 12520, Indonesia \\ Diterima tanggal: 24 September 2019 Diterima setelah perbaikan: 5 November 2019 \\ Disetujui terbit: 2 Desember 2019
}

\begin{abstract}
ABSTRAK
Penelitian ini bertujuan untuk mengidentifikasi faktor internal dan eksternal yang mempengaruhi pengembangan industri patin dan menentukan strategi prioritas untuk pengembangan industri patin di Provinsi Jambi. Penelitian dilaksanakan pada Bulan November 2018 hingga April 2019 bertempat di Provinsi Jambi (studi kasus di Kabupaten Muaro Jambi), dilakukan dengan metode SWOT (Strengths Weaknesses Opportunities and Threats) dan AHP (Analytical Hierarchy Process). Teknik pengumpulan data meliputi survei, observasi dan wawancara. Cakupan dalam penelitian ini mulai dari sektor budi daya, sektor pengolahan hingga pemasaran. Responden dalam penelitian ini adalah pelaku usaha, pembuat kebijakan (pemerintah daerah dan pusat), serta pakar (akademisi dan peneliti). Hasil identifikasi menunjukkan bahwa faktor internal dan eksternal yang mempengaruhi pengembangan industri patin pada aspek budi daya diantaranya status kepemilikan lahan, ketersediaan modal, tersedianya tenaga penyuluh perikanan, tingginya minat usaha, akses pemasaran, dukungan dan kebijakan dari pemerintah, dan kontinuitas bahan baku pakan. Pada aspek pengolahan, faktor yang mempengaruhi diantaranya lokasi unit pengolahan, ketersediaan bahan baku, tenaga kerja, akses pemasaran, dukungan pemerintah, serta persaingan. Analisis SWOT menghasilkan 8 alternatif strategi untuk budi daya dan 6 alternatif strategi di sektor pengolahan. Berdasarkan hasil analisis $A H P$, prioritas utama dalam pengembangan patin di Provinsi Jambi adalah meningkatkan pendampingan dan pembinaan kepada pembudi daya (sektor budi daya) dan mengembangkan usaha, diversifikasi dan inovasi produk (sektor pengolahan).
\end{abstract}

Kata Kunci: ikan patin; industri; Provinsi Jambi

\section{ABSTRACT}

The aims of this research were to identify internal and external factors and to formulate the alternative strategies in developing the pangasius industry, in Jambi Province. This research was held in November 2018 until April 2019 in Jambi Province (case study in Muaro Jambi district), applied SWOT (Strengths Weaknesses Opportunities and Threats) and AHP (Analytical Hierarchy Process) methods, while the data were obtained through survey, observation and interviews, covering aquaculture, processing and marketing sectors. Respondents in this research were businessmen, policy makers (local and central governments), and experts (academics and researchers). The results indicate that internal and external factors that influence the development of the pangasius industry in the aquaculture were land ownership, capital availability, availability of fisheries extension workers, high business interest, marketing access, support and policy from the government, and continuity of feed raw materials. Whereas in the processing include the location of processing units, the availability of raw materials, labor, marketing access, government support, and competition. SWOT analysis resulted in 8 alternative strategies for the aquaculture sector and 6 alternative strategies for processing sector. Based on AHP analysis, the main priorities for the development of pangasius industry in Jambi Province were to strengthen assistance and guidance for farmers (aquaculture sector) and business development, diversification and product innovation (processing sector).

Keywords: pangasius; industry; Jambi Province 


\section{PENDAHULUAN}

Ikan patin merupakan salah satu komoditas unggulan yang ditetapkan oleh Kementerian Kelautan dan Perikanan (KKP) dalam program percepatan industrialisasi perikanan budi daya. Peluang industri patin untuk konsumsi lokal sangat terbuka luas dengan adanya kebijakan larangan impor patin oleh KKP. Pasca penerapan kebijakan proteksi impor patin, geliat industri patin Indonesia menunjukkan perkembangan yang menggembirakan (Sari, 2018). Produksi patin nasional pada tahun 2015 sebanyak 339.069 ton, 437.111 ton pada tahun 2016, dan 604.587 ton di Tahun 2017 (Ditjen Perikanan Budi Daya, 2017). Dalam rangka mendorong produksi patin nasional, KKP mendirikan beberapa sentra produksi patin di Indonesia, salah satunya di Provinsi Jambi.

Pengembangan Provinsi Jambi untuk menjadi sentra ikan nasional komoditas patin masih terkendala masalah pemasaran (Ferdiyal, 2018), kurangnya modal usaha serta tingginya ongkos produksi. Adanya surplus produksi menunjukkan bahwa perkembangan industri hulu tidak diiringi perkembangan industri pada bagian hilir. Masalah pemasaran semakin terasa pasca tidak beroperasinya Unit Pengolahan Ikan (UPI) fillet patin yang ada di Kabupaten Muaro Jambi serta semakin sedikitnya jumlah unit pengolahan tradisional skala Usaha Mikro Kecil dan Menengah (UMKM) yang ada di daerah tersebut. Permasalahan lainnya yaitu kurangnya ketersediaan dan aksesibilitas modal sehingga pembudi daya kesulitan dalam menjalankan kegiatan dan mengembangkan usaha budi daya. Selain itu, ongkos produksi yang tinggi menjadi masalah di kalangan pembudi daya karena sulitnya memperoleh bahan baku pembuatan pakan mandiri sehingga pembudi daya tidak memiliki alternatif lain selain menggunakan pakan pabrikan dengan harga yang tinggi.

Berdasarkan permasalahan tersebut maka perlu didalami faktor-faktor apa saja yang dapat mempengaruhi pengembangan industrialisasi patin di Provinsi Jambi, baik faktor internal maupun eksternal, sehingga dapat diperoleh strategi pengembangan industrialisasi patin dengan harapan sektor industri patin di Provinsi Jambi dapat berkembang, berdaya saing, berkelanjutan serta dapat memperbaiki ekonomi masyarakat pembudi daya dan pengolah. Penelitian ini bertujuan untuk mengkaji faktor internal dan eksternal yang mempengaruhi pengembangan industrialisasi patin serta merumuskan alternatif strategi untuk pengembangan industri patin.

Penelitian dilakukan pada November 2018 s/d April 2019 bertempat di Provinsi Jambi, dengan studi kasus di Kabupaten Muaro Jambi. Kabupaten Muaro Jambi dipilih sebagai lokasi penelitian, mengingat kabupaten ini merupakan minapolitan untuk patin sesuai dengan Keputusan Menteri Kelautan dan Perikanan (KEPMEN KP) No. 32/Men/2010 tentang Penetapan Kawasan Minapolitan. Produksi patin di Kabupaten Muaro Jambi merupakan yang tertinggi di Provinsi Jambi, dengan produksi sebanyak 14.651 ton atau sekitar 68 persen dari produksi perikanan budi daya patin di Provinsi Jambi (Dinas Kelautan dan Perikanan Provinsi Jambi, 2018).

Pengumpulan data dan informasi dilakukan melalui survei dengan teknik wawancara dan observasi langsung pada lokasi pembudi daya ikan patin, unit pengolahan ikan patin, serta pasar yang menjual ikan patin. Teknik wawancara menggunakan kuesioner yang telah disediakan sebelumnya. Responden dalam penelitian ini adalah pelaku usaha (pembenih, pembudi daya, dan pengolah), konsumen, pembuat kebijakan yang expert di bidang budi daya dan pengolahan (Dinas Perikanan Kabupaten Muaro Jambi, Dinas Kelautan dan Perikanan (DKP) Provinsi Jambi, serta KKP), dosen perguruan tinggi yang expert di bidang budi daya dan pengolahan, peneliti di sektor budi daya, pengolahan, pasca panen dan sosial ekonomi, serta Asosiasi Pengusaha Catfish Indonesia (APCl).

Analisis data yang digunakan untuk menjawab tujuan penelitian adalah metode SWOT (Strengths, Weaknesses, Opportunities and Threaths) dan metode AHP (Analytical Hierarchy Process). Metode SWOT digunakan untuk memperoleh faktor-faktor internal dan eksternal yang mempengaruhi pengembangan industri patin di Provinsi Jambi yang selanjutnya digunakan untuk merumuskan alternatif strategi dalam pengembangan industri patin di Provinsi Jambi, sedangkan metode AHP digunakan untuk memilih strategi yang dihasilkan dari analisis SWOT sehingga diperoleh strategi prioritas dalam pengembangan industri patin di Provinsi Jambi. 


\section{FAKTOR LINGKUNGAN INTERNAL DAN EKSTERNAL INDUSTRI PATIN DI JAMBI}

Analisis lingkungan internal adalah suatu analisa yang dilakukan pada lingkungan yang berada dalam suatu organisasi ataupun suatu ruang lingkup yang memberikan implikasi langsung terhadap suatu kinerja organisasi tersebut dengan memanfaatkan kekuatan untuk meminimalisir kelemahan. Analisis eksternal merupakan suatu proses yang digunakan dalam perencanaan suatu strategi untuk memantau faktor luar berupa peluang dan ancaman yang ditentukan yang dapat mempengaruhi kinerja suatu perusahaan sehingga perusahaan dapat memanfaatkan peluang yang ada serta dapat mengantisipasi ancaman yang datang dari luar perusahaaan (Yanah, 2013). Berdasarkan hasil penelitian yang dilakukan, faktor lingkungan internal dan eksternal untuk strategi pengembangan industri budi daya patin di Provinsi Jambi dapat dilihat pada Tabel 1

\section{Industri Budi Daya Ikan Patin}

\section{A. Faktor Internal}

Kondisi geografis wilayah di Kabupaten Muaro Jambi khususnya Kecamatan Kumpeh Ulu dan Kecamatan Sungai Gelam memiliki lahan basah/rawa untuk budi daya ikan patin.
Hal ini sesuai dengan pernyataan Widodo, Akmal \& Syafrudin (2010) yang menyatakan bahwa komoditas yang cocok untuk dibudi dayakan di lahan tersebut adalah ikan patin karena ikan patin dapat tumbuh dengan baik serta dapat dikembangkan di lahan marjinal seperti lahan basah/rawa ataupun lahan gambut. Berdasarkan penelitian yang telah dilakukan pada pembudi daya patin menunjukkan bahwa mayoritas pembudi daya (sebanyak $74 \%$ ) mempunyai status kepemilikan lahan milik pribadi dengan sistem budi daya di kolam. Menurut Anwar (2013), status kepemilikan lahan menjadi kekuatan untuk meningkatkan produksi dan menjadi faktor yang mendukung dalam meraih kepercayaan untuk kerjasama dengan pihak yang terkait.

Dalam rangka meningkatkan komunikasi antara pemerintah dengan pembudi daya, maka dibentuklah kelompok budi daya (Pokdakan) dengan jumlah anggota 10-15 orang/kelompok, dipimpin seorang ketua kelompok dan di dampingi oleh tenaga penyuluh. Pembentukan Pokdakan sangat membantu kegiatan lembaga penyuluhan untuk menyampaikan informasi terkait kegiatan budi daya (sebagai media informasi dan komunikasi bagi anggota kelompok). Selain itu, di Provinsi Jambi terdapat Asosiasi Pembudi daya Patin Jambi (AP2J), asosiasi ini dibentuk sebagai wadah komunikasi antar pembudi daya

Tabel 1. Faktor Internal dan Eksternal Pengembangan Industri Budi Daya.

\begin{tabular}{lll}
\hline \multicolumn{1}{c}{ Kekuatan (Strengths) } & \multicolumn{1}{c}{ Kelemahan (Weaknesses) } \\
\hline 1) Sebanyak 74\% lahan budidaya adalah milik pribadi & 1) Keterbatasan ketersediaan dan aksesasilitas \\
modal & 2) Kualitas dan ketersediaan bibit tidak stabil \\
2) Adanya kelompok pembudidaya ikan (Pokdakan) & 3) Akses pemasaran sulit dan terbatas \\
3) Tersedianya tenaga penyuluh & 4) Penerapan Cara Budidaya Ikan yang Baik \\
4) Adanya Asosiasi Pengusaha Patin Jambi (AP2J) & 5) AP2J tidak berjalan \\
\hline 5) Kondisi geografis yang mendukung & \\
6) Tingginya minat budidaya & \\
7) Kerjasama pembudidaya dengan tauke pakan & \\
8) Tenaga kerja berpengalaman & \\
9) Kualitas ikan baik &
\end{tabular}

\section{Peluang (Opportunities)}

Ancaman (Threats)

1) Adanya larangan impor patin

1) Pasar dikelola oleh tengkulak

2) Kebijakan pemerintah menjadikan patin sebagai 2) Kontinuitas ketersediaan bahan baku pakan komoditas unggulan dan Provinsi Jambi sebagai salah satu sentra patin mandiri terbatas

3) Penetapan Kabupaten Muaro Jambi sebagai kawasan monapolitan

3) Serangan hama dan penyakit

4) Adanya dukungan pemerintah

5) Pemerintah mendorong kerjasama pembuatan vaksin

4) Harga pakan semakin mahal

5) Tidak beroperasinya UPI Fillet patin dan terbatasnya unit pengolahan ikan patin skala UMKM

6) Berkembangnya teknologi budidaya

6) Rusaknya jalur produksi di beberapa desa

7) Harga jual yang tidak stabil 
patin yang ada di Provinsi Jambi terkait segala hal dan informasi mengenai budi daya patin hingga pemasaran ikan patin. Kondisi yang ada saat ini menunjukkan bahwa AP2J tidak berjalan optimal. Tidak berjalannya AP2J ini disebabkan oleh tutupnya UPI fillet ikan patin yang ada di Provinsi Jambi, berkurangnya jumlah pembudi daya patin di beberapa daerah serta beralihnya komoditas yang dibudi dayakan oleh ketua AP2J tersebut.

Masih tingginya minat pembudi daya untuk memperbesar usaha budi dayanya, terbukti di beberapa tempat (Desa Lopak Alai dan Desa Tarikan) mencetak kolam-kolam baru secara masif. Selain itu, tingginya minat pembudi daya terlihat dari partisipasi pembudi daya dalam setiap kegiatan yang berkaitan dengan budi daya patin serta terus mencari ilmu agar lebih mendalami bidang usaha yang digeluti. Tingginya minat budi daya patin di kalangan pembudi daya tidak didukung dengan ketersediaan dan aksesibilitas modal usaha. Akibatnya banyak pembudi daya yang meminjam modal dan bekerja sama dengan tengkulak (tauke pakan).

Peminjaman modal ke tengkulak tersebut dilakukan oleh para pembudi daya dikarenakan tidak ada alternatif pinjaman lain. Peminjaman modal ke lembaga perbankan sulit untuk dilakukan dikarenakan pihak perbankan menginginkan adanya agunan sehingga hanya $3 \%$ pembudi daya saja yang melakukan peminjaman modal ke lembaga perbankan tersebut. Adanya kerjasama tersebut jika dilihat pada satu sisi menjadi kekuatan bagi pengembangan industri patin di Muaro Jambi dikarenakan kerjasama tersebut membantu pembudi daya dalam memperoleh modal produksi untuk penyediaan pakan. Disamping itu, terbatasnya informasi pemasaran ikan patin di kalangan pembudi daya menyebabkan para tengkulak membuat suatu kesepakatan (MoU) dengan pembudi daya untuk menampung serta memasarkan hasil panen pembudi daya yang meminjam modal kepada mereka. Sistem pembayaran pinjaman di akhir masa panen menjadi suatu kemudahan bagi para pembudi daya yang membutuhkan modal untuk kegiatan produksi. Di sisi lain, kerjasama antara pembudi daya dengan tengkulak menjadi kelemahan bagi para pembudi daya untuk menjalankan serta mengembangkan usaha budi daya, hal ini dikarenakan harga dan waktu panen ditentukan oleh tengkulak.

Dalam kegiatan budi daya ikan patin lebih bersifat kekeluargaan. Hal ini terlihat dari sumber tenaga kerja harian yang mengurus kolam budi daya yaitu anggota keluarga dari pelaku usaha itu sendiri. Kegiatan pemanenan ikan patin sebanyak $37 \%$ pembudi daya melakukan kegiatan pemanenan secara gotong royong dengan anggota kelompok budi daya, 63\% lainnya kegiatan pemanenan dilakukan oleh tenaga kerja harian yang berkisar 4-10 orang, tenaga kerja ini merupakan para pembudi daya patin yang terdapat di wilayah tersebut yang berpengalaman dalam kegiatan budi daya patin.

Kondisi di lokasi balai budi daya patin menunjukkan kualitas dan ketersediaan bibit patin yang tersedia di Provinsi Jambi tidak stabil. Benih patin yang diproduksi pada musim kemarau sulit untuk diperoleh dan cenderung mudah terserang penyakit. Ketersediaan bibit patin yang ada di Provinsi Jambi belum mampu untuk memenuhi kebutuhan pasar. Dilihat dari aspek teknis budi daya observasi menunjukkan bahwa penerapan CBIB di lokasi penelitian masih belum optimal. Hal ini ditandai dengan sedikitnya jumlah pembudi daya yang menerapkan, terbatasnya pembudi daya yang memperoleh sertifikat CBIB, serta sebagian pembudi daya bahkan belum mengerti mengenai CBIB. Ketidakpahaman sebagian pembudi daya mengenai CBIB dikarenakan kurangnya pengetahuan (tidak memiliki latar belakang pendidikan terkait budi daya), serta kurangnya pelatihan, penyuluhan maupun sosialisasi terkait dengan CBIB.

Kendala lain yang dihadapi pembudi daya yaitu kesulitan informasi untuk memasarkan hasil panen. Rantai pemasaran ikan patin yang ada di Provinsi Jambi yaitu dari pembudi daya selanjutnya diambil oleh para pengepul, seterusnya pemasaran dilakukan oleh pengepul ke Kaki/Agen dan selanjutnya dijual ke konsumen. Hasil observasi pada lokasi penelitian menunjukkan pemasaran ikan patin mayoritas dipasarkan di pasar lokal seperti Pasar Angso Duo dan pasar-pasar lain yang terdapat di kabupaten-kabupaten yang ada di Provinsi Jambi. Sedangkan pemasaran ke luar daerah masih terbatas dikarenakan banyak pembudi daya yang tidak mempunyai koneksi pasar di luar, selain itu letak Provinsi Jambi yang berada di tengah-tengah provinsi lainnya yang juga menjadi sentra patin nasional seperti Sumatera Selatan, Riau dan Lampung mempengaruhi akses pemasaran yang ada. 


\section{B. Faktor Eksternal}

Tahun 2011 KKP mengeluarkan Peraturan Menteri nomor 15 Tahun 2011 yang melarang impor produk fillet patin. Hal ini menjadi peluang bagi para pembudi daya patin untuk mengisi kekosongan pasokan impor sehingga konsumsi dalam negeri terpenuhi. Selain itu, tingginya produksi patin dapat dimanfaatkan untuk dilakukan kegiatan ekspor patin ke luar negeri, melihat bahwa tren impor patin di beberapa negara di dunia meningkat sehingga menjadi peluang untuk menguasai pasar global (Anonim, 2018). Berdasarkan data dari KKP tahun 2017, bahwa kebutuhan impor patin di China mencapai 34.000 ton per tahun, Thailand sebesar 19.300 ton per tahun dan Amerika Latin mengalami kenaikan hingga 12,3\% untuk kebutuhan impor patin. Dalam rangka mempercepat industrialisasi perikanan budi daya, pemerintah menjadikan patin sebagai salah satu komoditi utama dan menjadikan Provinsi Jambi sebagai salah satu sentra patin di Indonesia. Di Provinsi Jambi, penetapan Kabupaten Muaro Jambi sebagai kawasan minapolitan memudahkan informasi bagi pihak luar yang ingin bermitra.

Bentuk dukungan pemerintah dalam pengembangan industri patin yaitu adanya bantuan sarana dan prasarana, informasi maupun bimbingan teknis dalam bentuk penyuluhan, pembinaan, pendampingan, bantuan modal serta transfer teknologi yang dibutuhkan oleh pembudi daya. Selain itu, pemerintah setempat dalam hal ini Dinas Perikanan Kabupaten Muaro Jambi, DKP Provinsi Jambi serta Balai Budi Daya Air Tawar (BBAT) mendorong kembali kerjasama pembuatan vaksin Edwarsiella icthaluri yang mengakibatkan kematian tinggi pada kolam budi daya. Penyakit yang disebabkan oleh bakteri Edwarsiella icthaluri menuntut pemerintah setempat untuk kembali memproduksi vaksin. Pemerintah dalam hal ini Dinas Perikanan Kabupaten Muaro Jambi serta (BBAT) telah menjalin kerjasama dengan pihak Sanbe Farma dalam hal memproduksi vaksin Edwarsiella icthaluri. Hikmayani, Yulisti \& Hikmah (2012), menyebutkan bahwa faktor dominan yang berpengaruh dalam usaha budi daya ikan patin adalah secara teknis yaitu penyakit ikan, kualitas benih dan kualitas pakan; secara sosial adalah masih lemahnya kelembagaan permodalan; serta secara ekonomi yaitu harga benih dan harga pakan yang terus meningkat.
Teknologi budi daya ikan patin sudah berkembang dan dapat dimanfaatkan oleh pembudi daya untuk dapat meningkatkan kualitas, kuantitas serta produktivitas budi daya ikan patin. Teknologi ini merupakan hasil penelitian yang dilakukan oleh Perguruan Tinggi maupun Balai Riset Perikanan di Indonesia. Imawan (2014) menyatakan bahwa peningkatan teknologi serta manajemen dapat menghasilkan produksi yang maksimal dengan harga yang efisien dan kualitas yang baik sehingga akan meningkatkan daya saing di pasaran.

Kordi (2005) mengatakan bahwa pakan ikan merupakan komponen yang berpengaruh pada usaha budi daya ikan. Ketersediaan pakan dalam jumlah yang cukup, pemberian makan yang tepat waktu, dan bernilai gizi baik merupakan faktor penting dalam kegiatan budi daya ikan. Kondisi yang ada di lapangan menunjukkan bahwa kontinuitas ketersediaan bahan baku pembuatan pakan mandiri masih terbatas, sehingga para pelaku budi daya mulai beralih menggunakan pakan komersil. Tingginya harga pakan komersil menjadi ancaman dikarenakan mempengaruhi pengeluaran serta pendapatan akhir yang dihasilkan oleh pembudi daya, dan mempengaruhi keberlanjutan usaha budi daya patin yang ada. Seperti yang dinyatakan oleh Kordi (2005) bahwa sekitar $50-60 \%$ biaya produksi dikeluarkan untuk biaya pakan, sehingga manajemen pakan yang baik sangat diperlukan dalam pemilihan pakan atau pembuatan pakan, pengadaan, dan pemberian pakan yang terbaik harus diterapkan untuk menekan biaya produksi yang semakin tinggi.

Dalam pengembangan industri budi daya, ancaman yang dihadapi pembudi daya adalah informasi pasar dikuasai oleh para tengkulak/ tauke pakan (harga jual ikan dipasar dipermainkan dan ditentukan oleh para tengkulak) begitu pula dengan waktu panen. Selain itu, fluktuasinya harga jual patin dipengaruhi oleh jumlah pasokan yang masuk ke pasar (over produksi). Nilai harga ikan dapat menjadi lebih tinggi maupun lebih rendah tergantung jumlah produksi yang ada. Tidak stabilnya harga dapat mempengaruhi pendapatan akhir yang diperoleh oleh pembudi daya.

Keberadaan pabrik pengolahan fillet ikan patin dan industri pengolahan tradisional lainnya diperlukan untuk pengembangan industri patin pasca panen. Kondisi yang ada menunjukkan bahwa UPI fillet ikan patin (satu-satunya unit pengolahan skala besar di Provinsi Jambi) sudah 
tidak beroperasional lagi serta berkurangnya jumlah unit pengolahan tradisional skala UMKM. Beberapa penyebabnya diantaranya tidak adanya investor/ pihak yang mengelola UPI, sulitnya memperoleh bahan baku ikan patin untuk proses produksi, jangkauan pasar yang jauh serta adanya pembudi daya yang tidak beroperasional lagi. Keberadaan UPI dan unit pengolahan skala UMKM ini sangat membantu pembudi daya dalam menampung hasil panen pembudi daya sehingga terserap seluruhnya dan dapat menambah nilai jual produk dari yang biasa dijual dalam bentuk segar hidup menjadi aneka produk olahan yang bernilai tambah. Selain itu, keberadaan unit pengolah dapat membantu akses pemasaran patin bagi pembudi daya yang tidak memiliki akses koneksi pasar.

\section{Sektor Industri Pengolahan Ikan Patin}

Faktor-faktor internal dan eksternal yang mempengaruhi pengembangan industri pengolahan patin di Kabupaten Muaro Jambi dapat dilihat pada Tabel 2.

\section{A. Faktor Internal}

Lokasi unit pengolahan strategis dan dekat dengan sumber bahan baku ( \pm 1 kilometer). Hal ini menjadi pertimbangan penting bagi industri pengolahan karena jika lokasi bahan baku yang terlalu jauh akan membutuhkan sarana transportasi serta mengeluarkan ongkos angkutan, selain itu kualitas bahan baku juga menjadi salah satu faktor. Menurut Murniyati, Suryaningrum \& Fawzya
(2012) bahwa dekatnya jarak tempuh sumber bahan baku dengan unit pengolahan diperlukan agar lebih efisien serta mudah untuk dilakukan koordinasi terkait penyediaan bahan baku dan pemasaran. Dijelaskan oleh Poernomo (2013), patin merupakan produk biologi yang sangat mudah rusak (highly perishable) sehingga jarak antara sumber bahan baku dengan unit pengolahan yang dekat dapat menjaga kontinuitas dan kualitas suplai bahan baku.

Sumber bahan baku untuk kegiatan produksi diperoleh dari kolam budi daya milik sendiri dan pembudi daya lain di sekitar lokasi unit pengolahan. Selain itu, harga bahan baku (ikan patin) untuk pengolahan relatif murah. Murahnya harga bahan baku dikarenakan pengolah membeli langsung ke kolam pembudi daya dengan harga Rp15.000,-/ kg. Harga ini tergolong murah jika dibandingkan dengan harga di pasar Rp17.000 hingga Rp20.000,-/kg. Selain itu, jarak pembelian bahan baku yang cukup dekat dapat meminimalisir biaya pengangkutan ikan patin ke unit pengolahan.

Modal awal berasal dari modal pribadi dengan jumlah yang relatif rendah, berkisar antara Rp2.000.000 hingga Rp5.000.000,- menunjukkan bahwa dengan modal yang relatif rendah sudah bisa memproduksi produk olahan baik abon ikan patin dan kerupuk tulang ikan patin maupun stick ikan patin. Modal usaha merupakan faktor penunjang utama dalam suatu kegiatan yang dapat meningkatkan produksi. Tanpa adanya modal, pelaku usaha akan sulit untuk mengembangkan

Tabel 2. Faktor Internal dan Eksternal Pengembangan Industri Pengolahan.

\begin{tabular}{ll}
\hline \multicolumn{1}{c}{ Kekuatan (Strengths) } & \multicolumn{1}{c}{ Kelemahan (Weaknesses) } \\
\hline 1) Ketersediaan bahan baku & 1) Kurangnya informasi akses pemasaran \\
2) Modal pribadi yang terjangkau & 2) Jarak pasar jauh dari unit pengolahan \\
3) Lokasi strategis & 3) Volume produksi fluktuatif \\
4) Tenaga kerja berpengalaman & 4) Terbatasnya tenaga kerja di pemasaran \\
5) Kemasan produk menarik, produk bersertifikasi dan & 5) Daya tahan produk relatif rendah dan mudah \\
memiliki izin pengolahan & \\
6) Memiliki ruang pengolahan khusus & \\
7) Sistem nir-limbah & \\
8) Harga bahan baku (ikan patin) relatif murah &
\end{tabular}

2) Adanya bantuan sarana prasarana serta bimbingan teknis dari pemerintah

3) Aneka diversifikasi produk

4) Adanya kegiatan gerakan memasyarakatkan ikan

5) Program pemerintah dalam optimalisasi pengelolaan dan pemasaran produk hasil perikanan
1) Jumlah konsumen akhir fluktuatif

2) Adanya pesaing dari produk substitusi

3) Munculnya unit pengolahan baru atas program pemerintah

4) Permintaan akhir tidak stabil 
usahanya serta ketersediaan modal akan mempengaruhi produktivitas hasil usaha secara optimal (Aprolita, 2008).

Jumlah tenaga kerja di UMKM Tunas Baru sebanyak 12 orang dan UMKM Indri Jaya sebanyak 3 orang dengan pendidikan SLTP sederajat. Pengalaman tenaga kerja di dua UMKM tersebut dikatakan sudah cukup berpengalaman dikarenakan sudah bergabung berkerja selama 3-10 tahun. Tenaga kerja merupakan ibu rumah tangga yang bertempat tinggal di sekitar unit pengolahan.

Kemasan produk menarik serta produk sudah bersertifikasi dan memiliki izin pengolahan. Pengemasan memiliki tujuan agar produk tetap renyah karena bila produk tidak dikemas maka produk akan bersentuhan langsung dengan udara dan akan menyebabkan terjadinya oksidasi (rancidity). Produk yang dikembangkan oleh 2 (dua) UMKM sudah tersertifikasi, salah satunya dari Dinas Kesehatan yaitu sertifikasi P-IRT. Sertfikasi P-IRT diharapkan menjadi jaminan mutu produk sehingga dapat menembus pasar yang lebih luas (Sofia, 2011).

Unit pengolahan ikan yang ada memiliki ruang pengolahan khusus. Kontruksi bangunan unit pengolahan di 2 (dua) UMKM mempunyai bangunan yang berdampingan dengan rumah pemilik usaha dan terletak di pemukiman penduduk dengan ruang pengolahan disediakan khusus untuk proses pengolahan. Unit pengolahan sudah dirancang dan ditata, sehingga dapat dengan jelas memisahkan antar ruang yang satu dengan ruang yang lain dengan luas bangunan yang cukup memadai untuk kelancaran kerja.

Limbah sisa pengolahan dimanfaatkan seluruhnya (zero waste system). Dalam pengolahan abon ikan dan stick ikan patin, bagian yang digunakan hanya daging ikan patin saja yang telah dibersihkan dan dipisahkan dari kulit, tulang serta kepala ikan patin. Sedangkan bagian lainnya seperti kepala, tulang dan kulit di olah lagi menjadi produk lainnya yaitu kerupuk tulang ikan. Limbah berupa jeroan dimanfaatkan lagi menjadi pakan ternak baik diberikan langsung maupun diolah lebih lanjut menjadi tepung ikan untuk dijadikan pakan ternak. Sedangkan limbah cair bekas air pencucian dialirkan melalui saluran pembuangan.

Dalam kegiatan pemasaran, pengolah kekurangan informasi akses pemasaran (wilayah cakupan pemasaran masih sedikit). Kurangnya informasi pasar mengakibatkan UMKM hanya memproduksi dalam jumlah sedikit untuk penjualan ke swalayan yang menjadi target pasar sehingga tidak ada target produksi. Selain itu, jarak pasar jauh dari unit pengolahan. Jauhnya jarak pasar menjadi kelemahan bagi industri pengolahan dikarenakan membutuhkan tenaga kerja untuk mendistribusikan produk serta membutuhkan biaya tambahan untuk transportasi. Terbatasnya tenaga kerja di pemasaran produk mengakibatkan unit pengolahan kekurangan informasi mengenai kondisi dan ketersediaan produk di pasar akibatnya volume produksi menjadi tidak menentu. Mengingat daya tahan produk yang relatif rendah dan mudah rusak, maka produk harus di cek secara berkala di pasar setiap minggu untuk melihat kondisi produk.

\section{B. Faktor Eksternal}

Berdasarkan data yang diperoleh dari Dinas Perikanan Kabupaten Muaro Jambi terdapat 6 UMKM yang memproduksi abon ikan patin, 1 UMKM yang memproduksi stick ikan patin yang terdapat di sekitar Kabupaten Muaro Jambi, tetapi untuk saat ini UMKM tersebut sudah tidak beroperasi lagi. Sementara itu, produk kerupuk tulang ikan patin tidak terdapat pesaing. Hal ini menjadi peluang bagi 2 (dua) UMKM pengolahan produk ikan patin tersebut untuk terus mengembangkan usaha tersebut. Tetapi di sisi lain, terdapat adanya pesaing dari produk substitusi. Banyaknya jumlah pesaing substitusi menjadi ancaman bagi unit pengolahan karena konsumen menjadi lebih selektif dalam menetapkan keputusan produk yang dibeli apalagi jika produk substitusinya dapat memberikan manfaat sama.

Selain itu, jumlah permintaan konsumen akhir yang berfluktuasi mempengaruhi jumlah volume produksi suatu produk olahan, hal ini mengakibatkan suatu unit pengolahan tidak memiliki target produksi yang pasti serta mempengaruhi penjualan dan pendapatan yang diperoleh sehingga dapat mengancam keberlanjutan usaha dari suatu industri.

Pemberian bantuan yang diberikan oleh pemerintah kepada UMKM berupa bantuan modal, bantuan teknologi dan peralatan masak lainnya, perbaikan gedung pengolahan serta bantuan teknis seperti pelatihan dan pendampingan teknis. Selain itu, pemerintah juga mengadakan kegiatan gerakan memasyarakatkan makan ikan (Gemarikan). Gerakan ini bertujuan untuk 
meningkatkan permintaan masyarakat atas produk perikanan dan meningkatkan asupan gizi yang berasal dari ikan, sehingga berimplikasi pada peningkatan konsumsi ikan nasional. Bentuk kegiatan yang dilakukan KKP dalam gerakan memasyarakatkan makan ikan diantaranya adalah pameran produk, promosi di media massa, lomba masak serba ikan, bazaar produk dan kuliner perikanan, kerjasama mitra gemarikan, lomba inovasi menu masakan ikan, festival perikanan nusantara, pembentukan Forum Peningkatan Konsumsi Ikan (Forikan) tingkat daerah dan pusat, Rakor Gemarikan dan Forikan. Menurut Ramadhan (2017), gerakan memasyarakatkan ikan (Gemarikan) diharapkan dapat mendorong serapan pasar produk perikanan yang diikuti dengan naiknnya tingkat konsumsi ikan.

\section{Analisis SWOT}

Faktor internal dan eksternal yang diperoleh selanjutnya dilakukan pemberian nilai bobot dan rating dilakukan dengan menggunakan kuesioner skala likert ( 1 = tidak penting; 2 = kurang penting; 3 = biasa saja; 4 = penting; 5 = sangat penting) untuk pembobotan dan (1=kelemahan/ancaman besar, 2=kelemahan/ancaman kecil, 3=kekuatan/ peluang kecil; 4=kekuatan/peluang besar) untuk peratingan. Setelah pemberian nilai bobot dan rating selanjutnya ditentukan nilai skor dengan mengalikan antara bobot dan rating.

Jumlah responden yang terlibat sebanyak 11 orang, responden berasal dari pelaku usaha, penyuluh perikanan serta Dinas Perikanan Kabupaten Muaro Jambi dan DKP Provinsi Jambi. Matriks internal dan eksternal pengembangan industri budi daya patin dapat dilihat pada Tabel 3 dan Tabel 4, sedangkan matriks internal dan eksternal pengembangan industri pengolahan patin dapat dilihat pada Tabel 5 dan Tabel 6 .

Analisis SWOT dari masing-masing faktor internal dan eksternal tersebut, dapat dihitung selisih antara nilai kekuatan-kelemahan dan peluang-ancaman tersebut. Hasil perhitungan selisih tersebut merupakan faktor penentu pada matrik grand strateginya. Hal ini dapat dilihat pada Tabel 7.

Berdasarkan Tabel 7 terlihat bahwa dalam pengembangan industri patin di Kabupaten Muaro Jambi memiliki nilai faktor internal dengan bobot kekuatan yang lebih besar dibandingkan kelemahannya. Nilai faktor eksternal dengan bobot peluang yang lebih besar dari ancamannya. Nilai tersebut menunjukkan hasil selisih positif pada faktor internal maupun eksternal. Hasil analisis lingkungan internal dan eksternal kemudian ditentukan posisi strategi dengan menggunakan diagram SWOT seperti pada Gambar 1.

Tabel 3. Matriks Evaluasi Faktor Internal Pengembangan Industri Budi Daya.

\begin{tabular}{|c|c|c|c|c|}
\hline No & Faktor Internal & Bobot & Rating & Skor \\
\hline \multicolumn{5}{|c|}{ Kekuatan (Strengths): } \\
\hline 1. & $\begin{array}{l}74 \% \text { lahan budi daya berada di kawasan sentra patin adalah milik pribadi } \\
\text { dengan sistem budi daya kolam }\end{array}$ & 0,081 & 3,83 & 0,310 \\
\hline 2. & Terbentuknya Pokdakan dengan jumlah anggota $10-15$ orang/kelompok & 0,054 & 3,67 & 0,198 \\
\hline 3. & Tersedianya tenaga penyuluh perikanan & 0,087 & 4,00 & 0,348 \\
\hline 4. & Adanya AP2J & 0,078 & 2,67 & 0,208 \\
\hline 5. & Kondisi geografis wilayah yang mendukung kegiatan budidaya patin & 0,069 & 3,17 & 0,219 \\
\hline 6. & $\begin{array}{l}\text { Masih tingginya minat para pembudidaya untuk memperbesar usaha } \\
\text { budidayanya }\end{array}$ & 0,069 & 3,67 & 0,253 \\
\hline 7. & Adanya kerjasama pembudidaya dan penyuplai pakan & 0,057 & 2,83 & 0,161 \\
\hline 8. & Tenaga kerja pemanenan sudah berpengalaman & 0,075 & 3,17 & 0,238 \\
\hline \multirow[t]{3}{*}{9.} & Kualitas ikan yang dihasilkan baik & 0,081 & 4,00 & 0,324 \\
\hline & Sub Total & & & 2.260 \\
\hline & \multicolumn{4}{|l|}{ Kelemahan (Weaknesses): } \\
\hline 1. & $\begin{array}{l}\text { Kurangnya modal usaha sehingga banyak pembudidaya yang meminjam } \\
\text { modal kepada tengkulak (tauke pakan) }\end{array}$ & 0,078 & 1,83 & 0,144 \\
\hline 2. & Kualitas bibit patin yang tidak stabil & 0,066 & 2,33 & 0,154 \\
\hline 3. & Akses pemasaran yang masih sulit dan terbatas & 0,075 & 1,83 & 0,137 \\
\hline 4. & Penerapan CBIB belum optimal & 0,066 & 1,67 & 0,110 \\
\hline \multirow[t]{3}{*}{5.} & AP2J tidak berjalan optimal & 0,066 & 2,67 & 0,176 \\
\hline & Sub Total & & & 0,721 \\
\hline & Total & 1,00 & & 2,981 \\
\hline
\end{tabular}


Tabel 4. Matriks Evaluasi Faktor Eksternal Pengembangan Industri Budi Daya.

\begin{tabular}{|c|c|c|c|c|}
\hline No & Faktor Eksternal & Bobot & Rating & Skor \\
\hline & \multicolumn{4}{|l|}{ Peluang (Opportunities): } \\
\hline 1. & Adanya larangan impor patin oleh KKP & 0,086 & 3,67 & 0,316 \\
\hline 2. & $\begin{array}{l}\text { Kebijakan pemerintah yang menjadikan patin sebagai komoditi utama dan } \\
\text { menjadikan Provinsi Jambi sebagai salah satu sentra patin di Indonesia }\end{array}$ & 0,077 & 3,67 & 0,283 \\
\hline 3. & Penetapan Muaro Jambi sebagai kawasan minapolitan & 0,069 & 3,33 & 0,230 \\
\hline 4. & $\begin{array}{l}\text { Adanya dukungan pemerintah, adanya bantuan sarana dan prasarana } \\
\text { maupun bimbingan teknis }\end{array}$ & 0,083 & 4,00 & 0,332 \\
\hline 5. & $\begin{array}{l}\text { Pemerintah setempat mendorong kembali kerjasama pembuatan vaksin } \\
\text { Edwarsiella ichtaluri yang mengakibatkan kematian tinggi pada kolam }\end{array}$ & 0,074 & 3,00 & 0,222 \\
\hline \multirow[t]{3}{*}{6.} & Berkembangnya teknologi budi daya ikan patin & 0,083 & 3,83 & 0,318 \\
\hline & \multicolumn{3}{|l|}{ Sub Total } & 1,700 \\
\hline & \multicolumn{4}{|l|}{ Ancaman (Threats): } \\
\hline 1. & $\begin{array}{l}\text { Pasar dikelola oleh para ts engkulak (Harga jual ikan dipasar dipermainkan } \\
\text { dan ditentukan oleh para tengkulak) }\end{array}$ & 0,080 & 1,83 & 0,157 \\
\hline 2. & $\begin{array}{l}\text { Kontinuitas ketersediaan bahan baku pembuatan pakan mandiri yang } \\
\text { terbatas menyebabkan para pelaku budidaya mulai beralih menggunakan } \\
\text { pakan komersil }\end{array}$ & 0,077 & 1,33 & 0,110 \\
\hline 3. & $\begin{array}{l}\text { Serangan hama dan penyakit pada ikan patin yang mengakibatkan kematian } \\
\text { tinggi di beberapa kolam (serangan bakteri Edwarsiella ichtaluri) }\end{array}$ & 0,074 & 1,67 & 0,134 \\
\hline 4. & Harga pakan yang semakin mahal & 0,086 & 1,50 & 0,129 \\
\hline 5. & $\begin{array}{l}\text { Tidak beroperasinya pabrik UPI fillet ikan dan terbatasnya unit pengolahan } \\
\text { ikan patin skala UMKM }\end{array}$ & 0,072 & 1,83 & 0,132 \\
\hline 6. & Harga jual ikan patin konsumsi yang tidak stabil & 0.072 & 2.33 & 0.168 \\
\hline \multirow[t]{3}{*}{7.} & $\begin{array}{l}\text { Jalur produksi di beberapa desa (Desa Lopak Alai, Desa Tarikan) mengalami } \\
\text { kerusakan, agak menghambat proses mobilisasi ikan patin }\end{array}$ & 0.072 & 2.00 & 0.144 \\
\hline & Sub Total & & & 0,936 \\
\hline & Total & 1,00 & & 2,636 \\
\hline
\end{tabular}

Tabel 5. Matriks Evaluasi Faktor Internal Pengembangan Sektor Pengolahan.

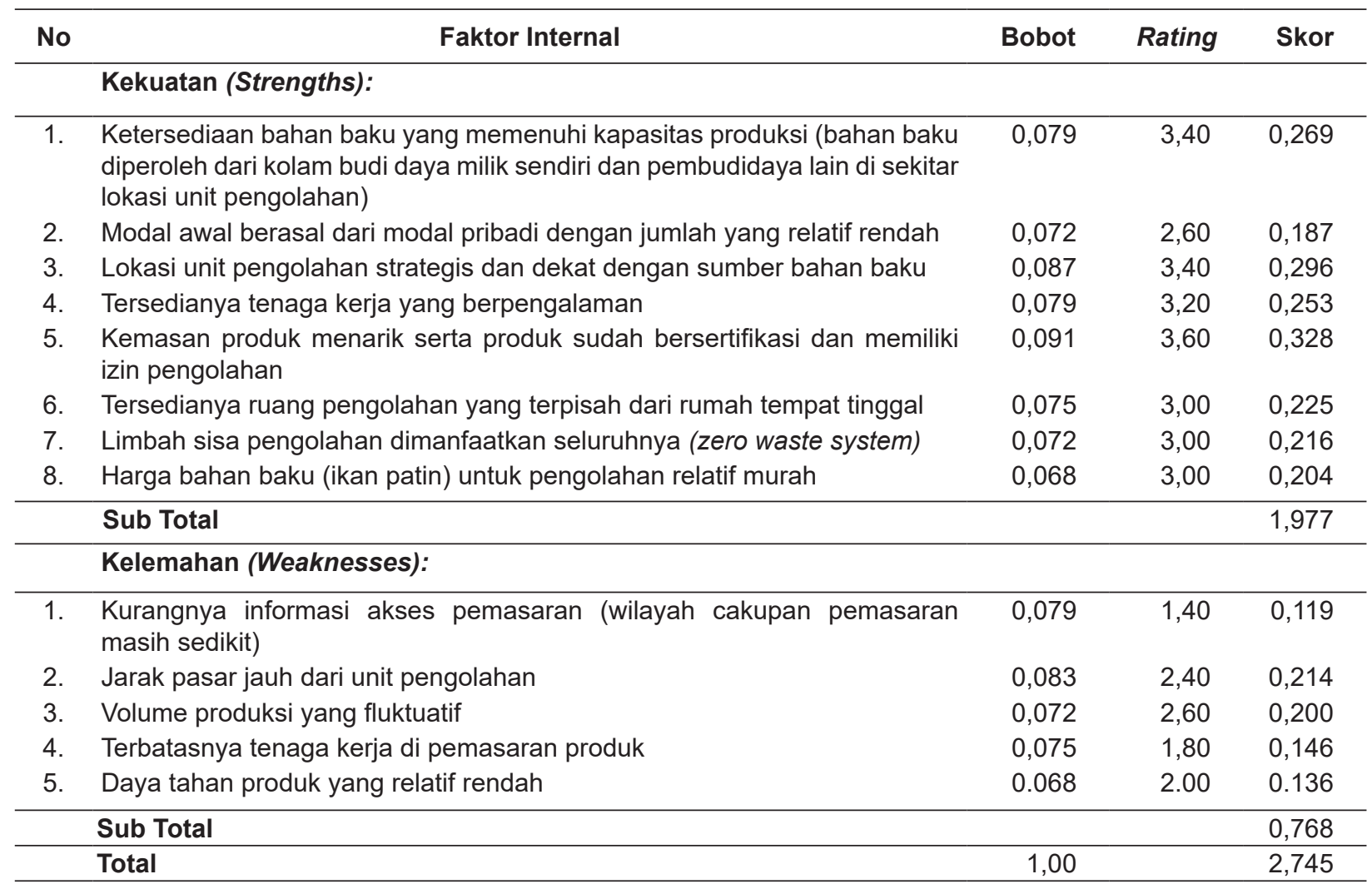


Tabel 6. Matriks Evaluasi Faktor Eksternal Pengembangan Sektor Pengolahan.

\begin{tabular}{|c|c|c|c|c|}
\hline No & Faktor Eksternal & Bobot & Rating & Skor \\
\hline \multicolumn{5}{|c|}{ Peluang (Opportunities): } \\
\hline 1. & Jumlah pesaing produk sejenis masih sedikit & 0,110 & 3,00 & 0,330 \\
\hline 2. & $\begin{array}{l}\text { Adanya dukungan pemerintah, adanya bantuan sarana dan prasarana } \\
\text { maupun bimbingan teknis }\end{array}$ & 0,127 & 3,00 & 0,381 \\
\hline 3. & Aneka diversifikasi produk olahan dari ikan patin & 0,092 & 2,60 & 0,239 \\
\hline 4. & Adanya kegiatan gerakan makan ikan & 0,116 & 2,80 & 0,325 \\
\hline 5. & $\begin{array}{l}\text { Adanya program pemerintah daerah dalam optimalisasi pengelolaan dan } \\
\text { pemasaran produk perikanan }\end{array}$ & 0,104 & 2,80 & 0,291 \\
\hline & Sub Total & & & 1,566 \\
\hline \multicolumn{5}{|c|}{ Ancaman (Threaths): } \\
\hline 1. & $\begin{array}{l}\text { Jumlah konsumen akhir berfluktuasi (tidak stabil) sehingga mempengaruhi } \\
\text { penjualan dan pendapatan }\end{array}$ & 0,121 & 2,20 & 0,266 \\
\hline 2. & Munculnya unit pengolahan baru & 0,110 & 1,80 & 0,198 \\
\hline 3. & Permintaan akhir tidak stabil & 0,110 & 2,60 & 0,286 \\
\hline 4. & Adanya pesaing dari produk lain & 0,110 & 2,20 & 0,242 \\
\hline \multicolumn{4}{|c|}{ Sub Total } & 0,992 \\
\hline & Total & 1,00 & & 2,558 \\
\hline
\end{tabular}

Tabel 7. Hasil Analisis SWOT Pengembangan Industri Patin di Muaro Jambi.

\begin{tabular}{lllll}
\hline No & \multicolumn{1}{c}{ Item } & Skor & Selisih & Nilai \\
\hline & Budi Daya & & & \\
\hline 1 & Kekuatan (S) & 2,260 & 1,539 & + \\
2 & Kelemahan (W) & 0,721 & \\
3 & Peluang (O) & 1,700 & 0,764 \\
4 & Ancaman (T) & 0,936 & \\
\hline & Pengolahan & 1,977 & 1,209 \\
2 & Kekuatan (S) & 0,768 & \\
3 & Pelemahan (W) & 1,566 & 0,574 \\
4 & Ancaman (T) & 0,992 & \\
\hline
\end{tabular}

Gambar 1 menjelaskan bahwa posisi industri budi daya dan industri pengolahan ikan patin berada pada kuadran 1 dengan nilai tertimbang kekuatan (S), kelemahan (W) sebagai titik koordinat $X$ pada sektor budi daya adalah 1,539 dan sektor pengolahan 1,209. Sedangkan nilai tertimbang peluang $(\mathrm{O})$, ancaman $(\mathrm{T})$ sebagai titik koordinat $Y$ pada sektor budi daya sebesar 0,764 dan sektor pengolahan 0,574. Rekomendasi yang diberikan adalah Agresif, artinya usaha ini dalam kondisi prima dan mantap sehingga sangat dimungkinkan untuk terus melakukan ekspansi, memperbesar pertumbuhan dan meraih kemajuan secara maksimal (Dedi, 2014). Menurut Rangkuti (2015), strategi yang harus diterapkan dalam kondisi ini adalah mendukung kebijakan pertumbuhan yang agresif (growth oriented strategy) atau strategi agresif (aggressive strategy). Hal ini merupakan suatu posisi yang sangat menguntungkan yakni memiliki peluang dan

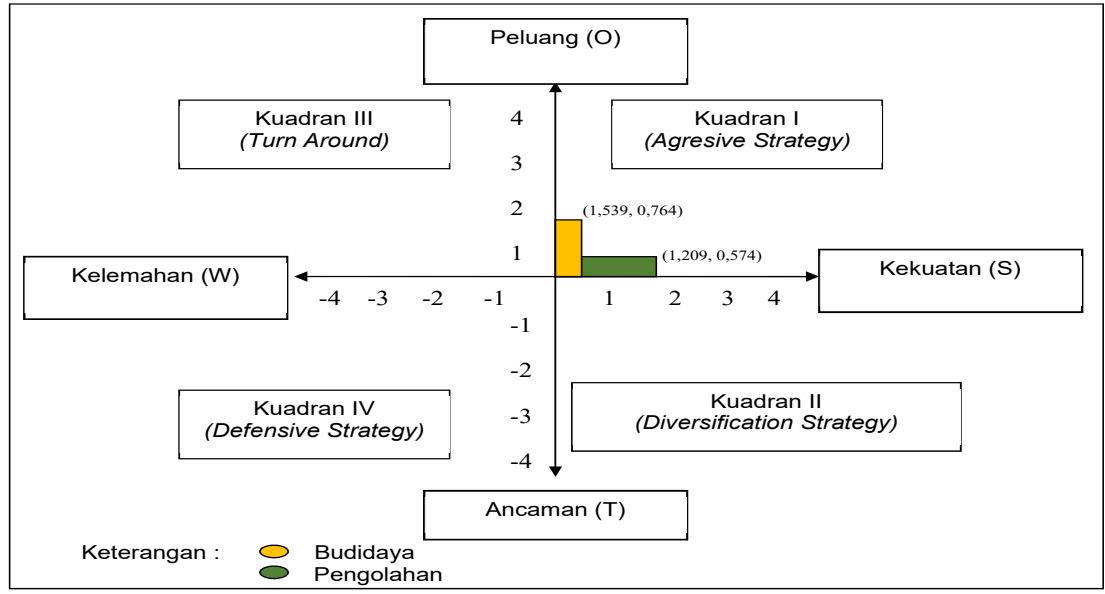

Gambar 1. Diagram Analisis SWOT Strategi Pengembangan Industri Patin. 
kekuatan sehingga dapat memanfaatkan peluang yang ada.

\section{ALTERNATIF STRATEGI PENGEMBANGAN INDUSTRI PATIN DI PROVINSI JAMBI}

Berdasarkan hasil identifikasi dan penilaian bobot serta rating faktor-faktor internal dan faktor-faktor eksternal dalam pengembangan industri patin di Provinsi Jambi, beberapa alternatif yang bisa dilakukan untuk mengembangkan industri patin dapat dilihat pada Tabel 8 (pengembangan industri patin di sektor budi daya) dan Tabel 9 (pengembangan industri patin di sektor pengolahan).

\section{PRIORITAS STRATEGI DALAM PENGEMBANGAN INDUSTRI PATIN}

Penggunaan SWOT dan AHP sudah pernah dilakukan sebelumnya oleh Kangas, Pesonen, Kurttila \& Kajanus (2001), Osuna \& Aranda (2007), Wickramasinghe \& Takano (2009), dan Ramadhan (2017). Dalam penentuan

Tabel 8. Matrik SWOT Pengembangan Industri Patin Sektor Budi Daya.

\begin{tabular}{|c|c|c|}
\hline Internal & Strengths (S) & Weaknesses (W) \\
\hline Eksternal & $\begin{array}{l}\text { 1. Tersedianya tenaga penyuluh } \\
\text { perikanan } \\
\text { 2. Kualitas ikan yang dihasilkan baik } \\
\text { 3. Status kepemilikan lahan budidaya } \\
\text { sebnayak } 74 \% \text { milik pribadi } \\
\text { 4. Masih tingginya minat para pembudi } \\
\text { daya }\end{array}$ & $\begin{array}{l}\text { 1. Penerapan CBIB belum optimal } \\
\text { 2. Akses pemasaran yang masih sulit } \\
\text { dan terbatas } \\
\text { 3. Kurangnya modal usaha sehingga } \\
\text { banyak pembudidaya yang } \\
\text { meminjam modal kepada tengkulak } \\
\text { (tauke pakan) }\end{array}$ \\
\hline Opportunities (O) & Strategi SO & Strategi WO \\
\hline $\begin{array}{l}\text { 1. Adanya dukungan dan bantuan dari } \\
\text { pemerintah } \\
\text { 2. Berkembangnya teknologi budidaya } \\
\text { ikan patin } \\
\text { 3. Adanya larangan impor patin oleh KKP } \\
\text { 4. Kebijakan pemerintah yang menjadikan } \\
\text { patin sebagai komoditi utama dan } \\
\text { menjadikan Provinsi Jambi sebagai } \\
\text { salah satu sentra patin di Indonesia }\end{array}$ & $\begin{array}{l}\text { 1. Pengembangan kawasan budidaya } \\
\text { dan peningkatan kapasitas produksi } \\
\text { 2. Memanfaatkan kemajuan teknologi } \\
\text { budidaya agar lebih produktif, efisien } \\
\text { serta menghasilkan produk ikan patin } \\
\text { yang lebih bermutu dan berdaya } \\
\text { saing }\end{array}$ & $\begin{array}{l}\text { 1. Pengoptimalan penerapan CBIB } \\
\text { 2. Memperluas akses lokasi } \\
\text { pemasaran serta meningkatkan } \\
\text { daya serap pasar terhadap ikan } \\
\text { patin }\end{array}$ \\
\hline Threats (T) & Strategi ST & Strategi WT \\
\hline $\begin{array}{l}\text { 1. Kontinuitas ketersediaan bahan baku } \\
\text { pembuatan pakan mandiri } \\
\text { 2. Harga pakan yang semakin mahal } \\
\text { 3. Tidak beroperasinya UPI fillet ikan dan } \\
\text { terbatasnya unit pengolahan ikan patin } \\
\text { skala UMKM } \\
\text { 4. Serangan hama dan penyakit pada } \\
\text { ikan patin }\end{array}$ & $\begin{array}{l}\text { Peningkatan pendampingan serta } \\
\text { pembinaan kepada pembudidaya } \\
\text { Membangun integrasi dari sektor } \\
\text { hulu hingga sektor hilir }\end{array}$ & $\begin{array}{l}\text { Penguatan kelembagaan dan } \\
\text { pengembangan kemitraan usaha } \\
\text { dengan pemerintah, investor, } \\
\text { pengusaha dan lembaga } \\
\text { perbankan untuk meningkatkan } \\
\text { akses terhadap permodalan, pasar } \\
\text { serta teknologi } \\
\text { Membangun sistem logistik pakan } \\
\text { mandiri }\end{array}$ \\
\hline
\end{tabular}

Tabel 9. Matrik SWOT Pengembangan Industri Patin Sektor Pengolahan.

\begin{tabular}{|c|c|c|}
\hline Internal & Strengths (S) & Weakness (W) \\
\hline Eksternal & $\begin{array}{l}\text { 1. Kemasan produk menarik serta } \\
\text { produk sudah bersertifikasi dan } \\
\text { memiliki izin pengolahan } \\
\text { 2. Lokasi unit pengolahan strategis dan } \\
\text { dekat dengan sumber bahan baku } \\
\text { 3. Ketersediaan bahan baku yang } \\
\text { memenuhi kapasitas produksi } \\
\text { 4. Tersedianya tenaga kerja yang } \\
\text { berpengalaman }\end{array}$ & $\begin{array}{l}\text { 1. Kurangnya informasi akses } \\
\text { pemasaran (wilayah cakupan } \\
\text { pemasaran masih sedikit) } \\
\text { 2. Daya tahan produk relatif rendah } \\
\text { 3. Terbatasnya tenaga kerja di } \\
\text { pemasaran produk }\end{array}$ \\
\hline Opportunities (O) & Strategi SO & Strategi WO \\
\hline $\begin{array}{l}\text { 1. Adanya bantuan sarana prasarana } \\
\text { serta bimbingan teknis dari pemerintah } \\
\text { 2. Jumlah pesaing produk sejenis masih } \\
\text { sedikit } \\
\text { 3. Adanya kegiatan gerakan makan ikan }\end{array}$ & $\begin{array}{l}\text { 1. Mengembangkan teknologi budidaya } \\
\text { ikan patin untuk menghasilkan bahan } \\
\text { baku untuk industri yang bermutu dan } \\
\text { berdaya saing } \\
\text { 2. Mengembangkan usaha, diversifikasi } \\
\text { dan inovasi produk dari ikan patin }\end{array}$ & $\begin{array}{l}\text { 1. Memperluas wilayah pemasaran } \\
\text { dan mempermudah distribusi produk } \\
\text { 2. Melakukan promosi, kampanye } \\
\text { dan berperan aktif dalam pameran } \\
\text { produk untuk memperkenalkan } \\
\text { pada masyarakat luas }\end{array}$ \\
\hline Threats (T) & Strategi ST & Strategi WT \\
\hline $\begin{array}{l}\text { 1. Adanya UMKM baru yang } \\
\text { memproduksi produk sejenis } \\
\text { 2. Adanya pesaing dari produk lain }\end{array}$ & $\begin{array}{l}\text { Meningkatkan mutu/kualitas, kuantitas } \\
\text { dan kontinuitas produk olahan ikan } \\
\text { patin }\end{array}$ & $\begin{array}{l}\text { Meningkatkan pengawasan } \\
\text { proses pengolahan serta } \\
\text { penjualan produk di pasar }\end{array}$ \\
\hline
\end{tabular}


prioritas strategi pengembangan patin di Provinsi Jambi digunakan alat analisis AHP (Analytical Hierarchy Process). Dalam penelitian ini, pengembangan industri patin di sektor budi daya maupun sektor pengolahan terdiri dari 4 (empat) kriteria yang telah ditentukan dan merupakan faktor yang dapat mempengaruhi serta menjadi pertimbangan dalam tercapainya suatu strategi. Penyusuan hierarki disusun menjadi 3 tingkatan prioritas kepentingan untuk fokus, kriteria dan alternatif strategi dengan menggunakan metode $A H P$.

Gambar 2 menunjukkan diagram hierarki kepentingan dalam pengembangan industri perikanan patin di Provinsi Jambi.

1. Fokus yaitu strategi pengembangan industri perikanan patin di Provinsi Jambi dengan studi kasus di Kabupaten Muaro Jambi.

2. Kriteria yaitu elemen/ukuran yang menjadi dasar penilaian yang dapat mempengaruhi keberhasilan penerapan alternatif strategi dari fokus yang ditetapkan. Hasil identifikasi yang diperoleh menunjukkan kriteria penentu yang mempengaruhi keberhasilan pengembangan industri patin di Provinsi Jambi, yaitu:
(1) Simplicity (K1);
(2) Biaya (K2);
(3) Sumber Daya Manusia (K3);
(4) Infrastruktur (K4).

Analisis pertama dilakukan penilaian bobot prioritas antar elemen yang sama. Kemudian dilanjutkan penilaian bobot prioritas dengan elemen 1 tingkat dibawahnya. Berdasarkan hasil nilai Eigen Vector/bobot dan setelah diuji konsistensinya maka prioritas elemen terhadap sasaran utama diuraikan sebagai berikut:

\section{A. Sektor Budi Daya}

\section{Kriteria Prioritas}

Kriteria prioritas yang mempengaruhi pengembangan industri patin di Provinsi Jambi adalah:

(1) Sumber daya manusia, dengan bobot 0,336 ;

(2) Infrastruktur, dengan bobot 0,324;

(3) Biaya, dengan bobot 0,198;

(4) Simplicity, dengan bobot 0,142.

2. Strategi prioritas

Pelaksanaan usaha pengembangan industri perikanan patin di Provinsi Jambi dapat dilakukan melalui beberapa strategi dengan prioritas sebagai berikut:

(1) Prioritas pertama adalah peningkatan pendampingan serta pembinaan kepada pembudi daya, dengan bobot 0,165 ;

(2) Prioritas kedua adalah pengoptimalan penerapan $\mathrm{CBIB}$, dengan bobot 0,154 ;

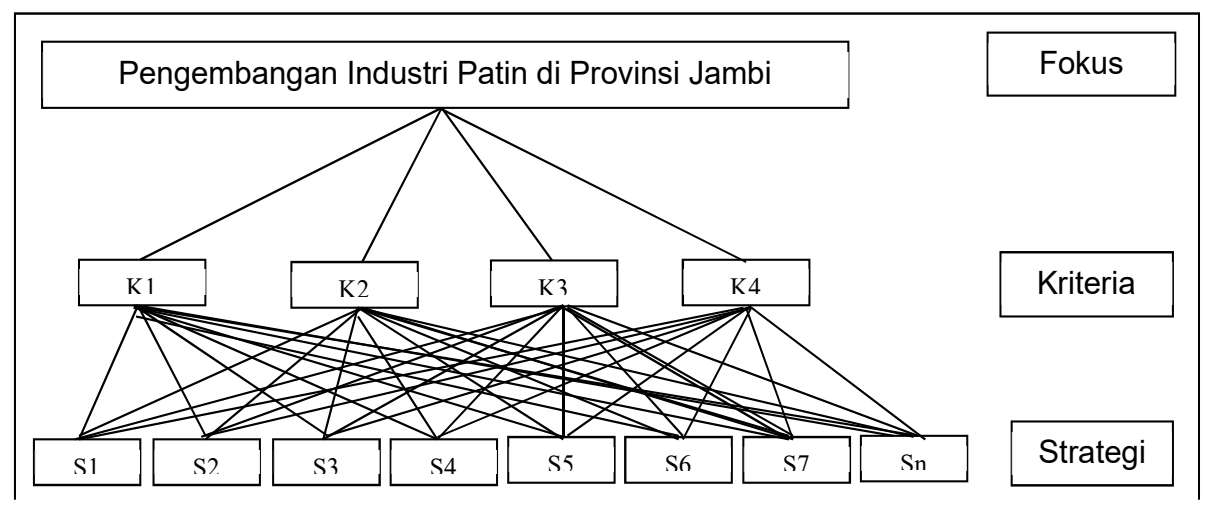

Gambar 2. Struktur Hierarki Pengembangan Industri Patin di Sektor Budi Daya dan Pengolahan.

Keterangan:

K = Kriteria (K1. Simplicity; K2. Biaya; K3. SDM; K4. Infrastruktur)

$\mathrm{S}=$ Strategi dalam sektor budidaya (S1. Pengembangan kawasan budidaya serta peningkatan kapasitas produksi; S2. Memanfaatkan kemajuan teknologi budidaya agar lebih produktif, efisien, serta menghasilkan produk ikan patin yang lebih bermutu dan berdaya saing; S3. Pengoptimalan penerapan CBIB; S4. Memperluas akses lokasi pemasaran serta meningkatkan daya serap pasar terhadap ikan patin; S5. Peningkatan pendampingan serta pembinaan kepada pembudidaya; S6. Membangun integrasi dari sektor hulu hingga sektor hilir; S7. Penguatan kelembagaan dan pengembangan kemitraan; S8. Membangun sistem logistik pakan mandiri).

$S=$ Strategi dalam sektor pengolahan (S1. Mengembangkan usaha, diversifikasi serta inovasi produk dari ikan patin; S2. Mengembangkan teknologi budidaya untuk menghasilkan bahan baku untuk industri pengolahan yang bermutu dan berdaya saing; S3. Memperluas wilayah pemasaran dan mempermudah distribusi produk; S4. Melakukan promosi, kampanye serta berperan aktif dalam pameran produk untuk memperkenalkan pada masyarakat luas; S5. Meningkatkan mutu kualitas, kuantitas dan kontinuitas produk olahan ikan patin; S6. Meningkatkan pengawasan proses pengolahan serta penjualan produk di pasar). 
(3) Prioritas ketiga adalah memanfaatkan kemajuan teknologi budi daya agar lebih produktif, efisien, serta menghasilkan produk ikan patin yang lebih bermutu dan berdaya saing, dengan bobot 0,151 ;

(4) Prioritas keempat adalah membangun sistem logistik pakan mandiri, dengan bobot 0,119 ;

(5) Prioritas kelima adalah memperluas akses lokasi pemasaran serta meningkatkan daya serap pasar terhadap ikan patin, dengan bobot 0,115 ;

(6) Prioritas keenam adalah membangun integrasi dari sektor hulu hingga sektor hilir, dengan bobot 0,107 ;

(7) Prioritas ketujuh adalah penguatan kelembagaan dan pengembangan kemitraan usaha dengan pemerintah, investor, pengusaha dan lembaga perbankan untuk meningkatkan akses terhadap permodalan, pasar serta teknologi, dengan bobot 0,100 ;

(8) Prioritas kedelapan adalah pengembangan kawasan budi daya serta peningkatan kapasitas produksi, dengan bobot 0,089 .

\section{B. Sektor pengolahan}

\section{Kriteria Prioritas}

Kriteria prioritas yang mempengaruhi pengembangan industri patin di Provinsi Jambi adalah:

(1) Sumber daya manusia, dengan bobot 0,353 ;

(2) Infrastruktur, dengan bobot 0,283;

(3) Biaya, dengan bobot 0,209;

(4) Simplicity, dengan bobot 0,154.

\section{Strategi prioritas}

Pelaksanaan usaha pengembangan industri perikanan patin di Provinsi Jambi dapat dilakukan melalui beberapa strategi dengan prioritas sebagai berikut:

(1) Prioritas pertama yaitu mengembangkan usaha, diversifikasi serta inovasi produk dari ikan patin adalah dengan bobot 0,229 ;

(2) Prioritas kedua adalah meningkatkan mutu kualitas, kuantitas dan kontinuitas produk olahan ikan patin, dengan bobot 0,175 ;
(3) Prioritas ketiga adalah memperluas wilayah pemasaran dan mempermudah distribusi produk dengan bobot 0,154 ;

(4) Prioritas keempat adalah meningkatkan pengawasan proses pengolahan serta penjualan produk di pasar, dengan bobot 0,153 ;

(5) Prioritas kelima adalah mengembangkan teknologi budi daya untuk menghasilkan bahan baku ikan patin yang bermutu dan berdaya saing, dengan bobot 0,149 ;

(6) Prioritas keenam melakukan promosi, kampanye dan berperan aktif dalam pameran produk untuk memperkenalkan pada masyarakat luas adalah dengan bobot 0,139 .

Berdasarkan hasil analisis AHP di atas dapat dikemukakan bahwa kriteria yang mempengaruhi pencapaian penerapan strategi pengembangan industri patin baik di sektor budi daya maupun sektor pengolahan adalah Sumber daya manusia. Sumber daya manusia memiliki peran penting dalam melaksanakan suatu program atau strategi guna mencapai tujuan yang diinginkan. Kesiapan Sumber daya manusia serta ketersediaan Sumber daya yang handal menjadi pendukung dalam mencapai strategi yang ada. Dalam rangka mencapai tujuan yaitu pengembangan industri patin di Provinsi Jambi maka prioritas strategi yang perlu dikembangkan adalah:

(1) Peningkatan pendampingan serta pembinaan kepada pembudi daya (Sektor Industri Budi daya)

Strategi peningkatan pendampingan dan pembinaan kepada pembudi daya ikan patin merupakan suatu upaya untuk meningkatkan dan mengembangkan kompetensi pembudi daya ikan patin dalam melaksanakan kegiatannya sehingga dapat meningkatkan produktivitas usaha, pendapatan serta kesejahteraan hidup pembudi daya. Menurut Cocon (2018), peran tenaga penyuluh sangat diperlukan untuk menampung permasalahan yang ada, menjadi mitra, motivator, fasilitator dan dinamisator bagi pelaku utama.

Di dalam strategi ini kegiatan pendampingan dan pembinaan dapat dilakukan melalui penyuluh perikanan, pihak BBAT, Lembaga Swadaya Masyarakat (LSM), maupun dari organisasi dan instansi terkait lainnya yang mampu dilibatkan dalam meningkatkan pendampingan dan pembinaan kepada pembudi daya. 
(2) Mengembangkan usaha, diversifikasi dan inovasi produk berbahan baku ikan patin (Sektor Industri Pengolahan)

Daya serap pasar yang rendah terhadap produksi ikan patin disebabkan oleh pemasaranyang masih bersifat lokal, rendahnya minat konsumen untuk mengkonsumsi produk serta serapan dari unit pengolahan masih sedikit. Upaya peningkatan daya serap pasar terutama di industri pengolahan, maka produk yang dihasilkan harus mempunyai keunggulan kompetitif dan mempunyai daya saing yang kuat. Strategi ini bertujuan untuk memperbesar usaha sehingga menambah pendapatan yang ada, selain itu pengembangan produk olahan baru yang sesuai dengan trend masyarakat, diversifikasi produk olahan berbasis ikan patin dilakukan untuk meningkatkan nilai tambah, menambah variasi jenis produk berbasis ikan patin, meningkatkan perekonomian masyarakat perikanan, dengan tujuan utama meningkatkan daya serap pasar. Chaidir, Napitupulu \& Sardi (2018) menyatakan bahwa keberlanjutan usaha pengolahan sebagai unit bisnis tidak bisa terlepas dari perubahan kondisi ekonomi, minat serta selera konsumen, sehingga suatu unit pengolahan diharapkan mampu untuk mempertahankan keberadaan dan melakukan alternatif pengembangan usaha pengolahan.

Strategi tersebut tidak hanya sebatas memproduksi produk yang bernilai kompetitif saja tetapi juga bagaimana produk yang dihasilkan oleh suatu unit pengolahan menerapkan zero waste system. Dengan penerapan sistem tersebut unit pengolahan diharapkan dapat menghasilkan keuntungan yang maksimal dan mengurangi limbah yang ada. Dalam industri pengolahan penerapan system nir-limbah/ zero waste system dilakukan dengan memanfaatkan semua bahan baku tanpa tersisa. Contoh pengaplikasian zero waste pada unit pengolahan adalah penggunaan daging ikan patin untuk pembuatan abon, kerupuk, siomay, nugget maupun aneka olahan lainnya. Bagian yang tersisa lainnya dapat dimanfaatkan seperti bagian kepala, tulang serta kulit ikan patin yang dapat diolah menjadi kerupuk, gulai, soup, dan lain sebagainya. Sedangkan untuk limbah jeroan dapat digunakan untuk pakan ternak maupun bahan baku untuk pembuatan pakan mandiri.

Strategi ini membutuhkan modal yang cukup serta keterlibatan tenaga kerja yang akan membantu untuk menerapkan strategi ini. Dalam pengembangan produk olahan baru perlu diarahkan pada permintaan pasar, sehingga diperlukan kegiatan penyuluhan dan pelatihan dari instansi terkait fokus pada pengembangan jenisjenis produk baru.

Dalam rangka pelaksanaan strategi prioritas dalam pengembangan industri patin di Provinsi Jambi perlu disusun programprogram maupun rencana aksi untuk menunjang keberhasilan pelaksanaan strategi terpilih tersebut. Program maupun rencana aksi yang akan dilaksanakan harus mempertimbangkan 3 hal yaitu: biaya pelaksanaan murah, dampaknya besar dan mudah untuk dilaksanakan. Penjelasan mengenai strategi terpilih dapat dilihat pada Tabel 10.

Tabel 10. Strategi Prioritas Terpilih Untuk Pengembagan Budi Daya Ikan Patin

\begin{tabular}{|c|c|c|c|c|}
\hline Strategi & Tujuan & $\begin{array}{c}\text { Indikator } \\
\text { keberhasilan }\end{array}$ & Syarat & Rencana Aksi \\
\hline $\begin{array}{l}\text { Peningkatan } \\
\text { pendampingan dan } \\
\text { pembinaan }\end{array}$ & $\begin{array}{l}\text { Meningkatkan dan } \\
\text { mengembangkan } \\
\text { kompetensi pembudi } \\
\text { daya ikan patin } \\
\text { dalam melaksanakan } \\
\text { kegiatannya } \\
\text { sehingga dapat } \\
\text { meningkatkan } \\
\text { produktivitas usaha, } \\
\text { pendapatan serta } \\
\text { kesejahteraan hidup } \\
\text { pembudi daya }\end{array}$ & $\begin{array}{l}\text { 1) Meningkatnya } \\
\text { kemandirian } \\
\text { pembudi daya ikan } \\
\text { patin } \\
\text { 2) Tingginya antusias } \\
\text { pembudi daya terkait } \\
\text { kegiatan budi daya } \\
\text { 3) Meningkatnya } \\
\text { produksi ikan patin } \\
\text { 4) Meningkatnya } \\
\text { pendapatan pembudi } \\
\text { daya }\end{array}$ & $\begin{array}{l}\text { 1) Tersedianya tenaga } \\
\text { penyuluh perikanan } \\
\text { dengan jumlah } \\
\text { yang sesuai } \\
\text { 2) Adanya komunikasi } \\
\text { yang baik antara } \\
\text { pembudi daya } \\
\text { dengan penyuluh } \\
\text { maupun lembaga } \\
\text { yang memberikan } \\
\text { pendampingan dan } \\
\text { pembinaan }\end{array}$ & $\begin{array}{l}\text { 1) Mengadakan seminar, } \\
\text { penyuluhan, pelatihan } \\
\text { 2) Pendampingan pembuatan pakan } \\
\text { 3) Mengadakan pertemuan rutin } \\
\text { 4) Sosialisasi program-program } \\
\text { 5) Mengadakan studi banding ke } \\
\text { lokasi sentra budi daya yang lebih } \\
\text { maju } \\
\text { 6) Membuat kelompok usaha } \\
\text { percontohan dan kelompok } \\
\text { binaan } \\
\text { 7) Pendampingan penguatan } \\
\text { semangat budi daya } \\
\text { 8) Pendampingan uji kualitas air, } \\
\text { kandungan gizi serta hama dan } \\
\text { penyakit } \\
\text { 9) Memfasilitasi bimbingan teknis, } \\
\text { bantuan dan permodalan }\end{array}$ \\
\hline
\end{tabular}


Tabel 11. Strategi Prioritas Terpilih Untuk Usaha Pengolahan Ikan Patin.

\begin{tabular}{|c|c|c|c|c|}
\hline Strategi & Tujuan & Indikator keberhasilan & Syarat & Rencana Aksi \\
\hline $\begin{array}{l}\text { Pengembangan } \\
\text { usaha, diversifikasi } \\
\text { dan inovasi produk } \\
\text { berbahan baku dari } \\
\text { ikan patin }\end{array}$ & $\begin{array}{l}\text { 1) Memperbesar usaha } \\
\text { sehingga menambah } \\
\text { pendapatan yang ada } \\
\text { 2) Meningkatkan nilai } \\
\text { tambah } \\
\text { 3) Menambah variasi } \\
\text { jenis produk berbasis } \\
\text { ikan patin } \\
\text { 4) Meningkatkan } \\
\text { perekonomian } \\
\text { masyarakat } \\
\text { perikanan, dengan } \\
\text { tujuan meningkatkan } \\
\text { daya serap pasar. }\end{array}$ & $\begin{array}{l}\text { 1) Meningkatnya omset } \\
\text { pendapatan } \\
\text { 2) Berkembangnya dan } \\
\text { bertambahnya jumlah } \\
\text { unit pengolahan } \\
\text { 3) Meningkatnya minat } \\
\text { konsumsi masyarakat } \\
\text { terhadap produk olahan } \\
\text { 4) Terbukanya lokasi } \\
\text { pemasaran }\end{array}$ & $\begin{array}{l}\text { 1) Tersedianya sumber } \\
\text { daya manusia yang } \\
\text { berkompetensi } \\
\text { 2) Tersedianya biaya } \\
\text { yang cukup } \\
\text { 3) Adanya sarana } \\
\text { prasarana untuk } \\
\text { produksi } \\
\text { 4) Tersedianya } \\
\text { pendamping teknis } \\
\text { untuk mentransfer } \\
\text { ilmu dan informasi }\end{array}$ & $\begin{array}{l}\text { 1) Pemerintah memberikan } \\
\text { informasi jaringan } \\
\text { pemasaran } \\
\text { 2) Mengadakan seminar. } \\
\text { pembinaan dan pelatihan } \\
\text { 3) Mengadakan pertemuan } \\
\text { rutin } \\
\text { 4) Studi banding ke } \\
\text { perusahaan pengolahan } \\
\text { 5) Memanfaatkan TIK untuk } \\
\text { menjalankan strategi } \\
\text { 6) Membuat kelompok } \\
\text { usaha percontohan } \\
\text { 7) Memberikan magang di } \\
\text { perdagangan } \\
\text { 8) Mengadakan dan } \\
\text { memfasilitasi pertemuan } \\
\text { bisnis pelaku usaha } \\
\text { 9) Memfasilitasi sarana } \\
\text { prasarana, akses bantuan } \\
\text { dan permodalan }\end{array}$ \\
\hline
\end{tabular}

Strategi untuk pengembangan industri pengolahan ikan yaitu pengembangan usaha, diversifikasi dan inovasi produk berbahan baku ikan patin. Rincian strategi terpilih dapat dilihat pada Tabel 11.

\section{PENUTUP}

Pengembangan industri patin di Provinsi Jambi dipengaruhi oleh 14 faktor internal dan 13 faktor eksternal yang mempengaruhi pengembangan industri budi daya patin di Provinsi Jambi. Faktor yang mempengaruhi pengembangan industri pengolahan ikan patin terdiri dari 13 faktor internal dan 9 faktor eksternal. Faktor internal maupun eksternal yang mempengaruhi pengembangan industri budi daya dan pengolahan yang ada di Provinsi Jambi setelah di analisis dengan menggunakan SWOT diperoleh 8 (delapan) alternatif strategi untuk industri budi daya dan 6 (enam) alternatif strategi dalam pengembangan industri pengolahan. Setelah dilakukan pengolahan data dengan menggunakan AHP maka prioritas strategi yang diperoleh dalam rangka mengembangkan industri patin di sektor budi daya adalah peningkatan pendampingan serta pembinaan kepada pembudi daya. Prioritas strategi dalam mengembangkan industri pengolahan adalah pengembangan usaha, diversifikasi dan inovasi produk berbasis ikan patin.

\section{UCAPAN TERIMA KASIH}

Penulis mengucapkan terima kasih kepada Dinas Perikanan Kabupaten Muaro Jambi, DKP Provinsi Jambi, penyuluh perikanan bantu
Kabupaten Muaro Jambi (Bapak Luqman, Ibu Ibu Asri Arti Erfita, dan Bapak Febri) yang telah mendampingi penulis selama penelitian, serta terimakasih kepada para responden yang terlibat dalam penelitian ini atas informasi dan penilaian yang telah diberikan.

\section{DAFTAR PUSTAKA}

Anonim. (2018). Tren \& Pasar Baru Fillet Patin. Majalah Trubus September 2018/XLIX. HIm 18.

Anwar, A. (2013). Analisis Kebijakan dan Strategi Pengembangan Usaha Rumput Laut Euchema cottoni di Kabupaten Bantaeng (Studi Kasus di Kecamatan Bissappu, Bantaeng dan Paa'jukukang). Octopus Jurnal IImu Perikanan. Vol 1(2): hlm 103-109. Retrieved from https:// journal.unismuh.ac.id/index.php/octopus/article/ download/521/481.

Aprolita. (2008). Kemandirian Pembudi daya Ikan Patin di Kolam Lahan Gambut di Desa Tangkit Baru, Kec Kumpeh Ulu, Kab Muaro Jambi, Provinsi Jambi. [TESIS]. Bogor: Program Sudi IImu Penyuluhan Pembangunan. Institut Pertanian Bogor.

Chaidir, N., Napitupulu, D. \& Sardi, I. (2018). Strategi Pengembangan Agroindustri Ikan Patin (Studi Kasus di Desa Pudak Kecamatan Kumpeh Ulu Kabupaten Muaro Jambi). Jurnal IImiah SosioEkonomika Bisnis. Vol 21(1): hlm 1-13. Retrieved from https://online-journal.unja.ac.id/jseb/article/ view/5099.

Cocon. (2018). Akuakultur dalam Perspektif Pembangunan Berkelanjutan. Jakarta, ID: Kencana Batu Pualam (KRP) Press. 
Dedi, A.K. (2014). Prosfek Kelayakan dan Strategi Pengembangan Pembenihan Lele (clarias sp.) di Desa Babakan, Kecamatan Ciseeng, Kabupaten Bogor. [TESIS]. Bogor: Program Studi Industri Kecil Menengah. Institut Pertanian Bogor.

[DJPB] Direktorat Jenderal Perikanan Budi daya. (2017). Statistik Perikanan Budi daya 2016. Direktorat Jenderal Perikanan Budi daya Kementerian Kelautan dan Perikanan.

[DKP] Dinas Kelautan dan Perikanan Provinsi Jambi. (2018). Buku Tahunan Perikanan dalam Angka Tahun 2017. Dinas Kelautan dan Perikanan Provinsi Jambi.

Ferdiyal, I. (2018). Terkendala Pemasaran, Sentra Patin Nasional Belum Terealisasi. Retrieved from https://metrojambi.com/read/2018/06/22/37382/ terkendala-pemasaran-sentra-patin-nasional-belum-terealisasi.

Hikmayani, Y., Yulisti, M., \& Hikmah. (2012). Evaluasi Kebijakan Peningkatan Produksi Perikanan Budi daya. Jurnal Kebijakan Sosial Ekonomi Kelautan dan Perikanan. Vol 2(2): hlm 85-102.

Imawan, T.Y. (2014). Strategi Pengembangan Pembenihan Ikan Patin (Pangasius hypopthalmus) di Kecamatan Ciampea Kabupaten Bogor. Jurnal Manajemen Perikanan dan Kelautan. Vol 1(1): hlm 1-13.

Kangas, J., Pesonen, M., Kurttila, M., \& Kajanus, M. (2001). A'WOT: Integrating The AHP With SWOT Analysis. Proseedings-6th ISAHP 2001 Berne, Switzerland. HIm 189-198.

Kordi, K.M.G.H. (2005). Budi daya Ikan Patin Biologi, Pembenihan dan Pembesaran. Yogyakarta, ID: Yayasan Pustaka Nusatama.

[KKP] Keputusan Menteri Kelautan dan Perikanan (Kepmen-KP) Nomor 32 Tahun 2010. Penetapan Kawasan Minapolitan. 14 Mei 2010.

[KKP] Peraturan Menteri Kelautan dan Perikanan (Permen-KP) Nomor 15Tahun 2011. Pengendalian Mutu dan Keamanan Hasil Perikanan yang Masuk ke dalam Wilayah Negara Republik Indonesia. 15 Juni 2011.

Murniyati., Suryaningrum. \& Fawzya. (2012). Analisis Kebijakan Pengembangan Industri Pengolahan Hasil Perikanan dan Kelautan 2012. "Industrialisasi Patin, Pindang \& Fillet Ikan". Balai Besar Penelitian dan Pengembangan Pengolahan Produk dan Bioteknologi Kelautan dan Perikanan. ISBN:978-602-19699-3-9.
Osuna, E.E., \& Aranda, A. (2007). Combining SWOT and AHP Techniques for Strategic Planning. ISAHP 2007. Vina del Mar, Chile, August 2-6,2007. HIm 1-8.

Poernomo, A. (2013). Industri Patin : Efisiensi dan Focus ke Konsumen. Retrieved from achpoer.blogspot. com/2013/02/patin.html.

Ramadhan, A. (2017). Strategi Penguatan Daya Saing Fillet Patin Indonesia. [TESIS]. Bogor : Program Studi Teknologi Hasil Perairan. Institut Pertanian Bogor.

Rangkuti, F. (2015). Teknik Membedah Kasus Bisnis Analisis SWOT (Cara Perhitungan Bobot, Rating dan OCAl). Jakarta, ID: PT. Gramedia Pustaka Utama.

Sari, S.M. (2018). Impor dari Vietnam dihentikan, Produksi Ikan Patin Meningkat. Retrieved from http://m. bisnis.com/amp/read/20180411/99/783179/ impor-dari-vietnam-dihentikan-produksi-ikan-patin-meningkat.

Sofia, L.A. (2011). Analisis Prospek Industri Pengolahan Kerupuk Ikan Patin "Intan Sari" di Martapura, Kabupaten Banjar. Jurnal IImu Perikanan. Vol 1(2): hlm 146-160. Retrieved from https:// www.researchgate.net/publication/306104123_ analisis_prospek_industri_pengolahan_ kerupuk_ikan_patin_intan_sari_di_martapura_ kabupaten_banjar_prospect_analysis_of_ catfish_crackers_processing_industry_intan_ sari_in_martapura_banjar_district.

Wickramasinghe, V. \& Takano, S. (2009). Application of Combined SWOT and Analytic Hierarchy Process $(A H P)$ for Tourism Revival Strategic Marketing Planning: A Case of Sri Lanka Tourism. Journal of the Eastern Asia Society for Transportation Studies. Vol 8. hlm 1-16.

Widodo, P., Akmal. \& Syafrudin. (2010). Budi daya Ikan Patin (Pangasius hypophthalmus) pada Lahan Marjinal di Kabupaten Pulau Pisang di Provinsi Kalimantan Tengah. Prosiding Forum Inovasi Teknologi Akuakultur 2010. hlm 49-60.

Yanah, L. (2013). Analisis Strategi Pengembangan Usaha Pembenihan Ikan Patin Siam di Darmaga Fish Culture. [TESIS]. Bogor : Fakultas Ekonomi dan Manajemen. Institut Pertanian Bogor. 